\title{
STUDIJE ŽENSKE I FEMINISTIČKE PERIODIKE U ČASOPISU "KNJIŽENSTVO"
}

Knjiženstvo: časopis za studije književnosti, roda i kulture predstavlja dio projekta iz digitalne humanistike pod nazivom Knjiženstvo, teorija i istorija ženske književnosti na srpskom jeziku do 1915. godine, koji je pokrenut 2011. godine. Nastanak časopisa usko je vezan za prethodno uobličeni kontekst koji su ocrtali časopisi koje od 1990-ih godina izdaje Centar za ženske studije - Ženske studije (1995-2002) i Genero (2002- ). U prvom dijelu rada analiziraće se opšte odlike časopisa: glavne karakteristike, ciljevi i struktura, dok ce se u drugom delu fokus biti na radovima o ženskoj i feminističkoj periodici. Analiza će biti ograničena na tekstove Ane Kolarić i Jelene Milinković posvećene časopisu Žena o kojem je u toj oblasti napisan najveći broj radova (ukupno pet). Zastupljenost ovog časopisa potvrđuje da je riječ o značajnom izvoru iz kojeg se može rekonstruisati pozicija žene u istorijskom i kulturnom kontekstu tadašnje epohe. Analiza datih radova podrazumijeva prikaz najznačajnijih aspekata koje autorke predstavljaju, te pokušaj sažimanja nji- 
hovih opštih zaključaka u svrhu formiranja opšte slike o emancipatorskim diskursima u Srbiji s početka 20. vijeka.

Ključne reči: Knjiženstvo, Žena, Milica Tomić, studije periodike, emancipatorsko-feministički diskursi u Srbiji krajem 19. i početkom 20. vijeka

\section{UVOD}

Projekat Knjiženstvo je rezultat uspješne implementacije relativno nove naučne discipline - digitalne humanistike. Pored časopisa, projekat čini i digitalna baza podataka Knjiženstvo, teorija i istorija ženske književnosti na srpskom jeziku do 1915. godine, u kojoj su sadržani podaci o stvaralaštvu srpskih književnica od srednjeg vijeka do 1915. godine. U ovaj vremenski okvir smještaju se sve autorke koje su $\mathrm{u}$ ovom periodu bile aktivne u domenu književnog stvaralaštva, a ne samo one čija su djela do 1915. godine i objavljena. Časopis i digitalna baza podataka su međusobno povezani, a baza je formirana po uzoru na evropsku bazu Women Writers, sa kojom je isto tako povezana. U bazi su sadržani osnovni biografski i bibliografski podaci, podaci o prevodima, ženskim časopisima, vezama sa drugim književnicama i njihovim međusobnim uticajima, uz linkove koji vode ka digitalizovanim tekstovima. ${ }^{1}$ Ovakva umreženost očitovana u vidu elektronske veze koja vodi direktno od teksta u časopisu do baze podataka potspješuje brz i efikasan protok informacija a samim tim i sveobuhvatnije i cjelovitije razumjevanje čitanog teksta.

Časopis Knjiženstvo je isključivo elektronski i izlazi kao godišnjak, a od njegovog pokretanja 2011. godine pa do danas objavljeno je ukupno šest brojeva. ${ }^{2}$ Časopis je na listi Ministarstva prosvete, nauke i tehnološkog razvoja Srbije, međunarodno je orijentisan, o čemu svjedoče radovi iz regiona i šire, a pored EBSCO baze nalazi se i u bazi CEEOL. Digitalni format časopisa Knjiženstvo progresivan je ne samo u sferi feminističke štampe, već i u sferi akademskog izdavaštva u Srbiji i regionu. Progresivnost se ogleda prije svega u činjenici da je tendencija ka digitalizaciji akademskih časopisa u svijetu sve zastupljenija, ali da su još uvijek rijetki akademski časopisi koji izlaze isključivo u elektronskom obliku (pretežno je elektronski oblik samo prateći ili dodatni uz štampanu formu).

1 Knjiženstvo, početna strana: http://www.knjizenstvo.rs/index.php 2 Ovaj rad je pisan u leto/jesen 2017. godine. 
Sam naziv “knjiženstvo" je zapravo nekadašnji termin za književnost koji je u upotrebi bio u dubrovačkom jeziku, a u ovom kontekstu nastaje kao rezultat poetične igre riječima u kojoj se sjedinjuju osnovni elementi projekta: “[...] književnost i žensko stvaralaštvo na jednom jeziku i njegovim pretečama, kao i nastojanje da se pronađe teorijski govor kojim se to stvaralaštvo može opisati." 3 Časopis je zamišljen "[...] kao prostor u kome mapa ženske književnosti u nastajanju biva uobličena u narativ, oživljena kao niz dijaloga, obrazlagana, preispitivana, teoretizovana i povezana sa različitim pristupima i disciplinama". ${ }^{4}$

Kako je navedeno u prvom broju časopisa, primarni cilj cjelokupnog projekta jeste da "[...] osvetli istoriju ženske književnosti na srpskom jeziku kao i da teoretizuje njene specifičnosti, preoblikujući postojeće, uglavnom zapadne, pojmove i modele”. ${ }^{5}$

\section{STRUKTURA ČASOPISA "KNJIŽENSTVO"}

Časopis Knjiženstvo od prvog do šestog broja odlikuje ustaljena i precizno određena struktura koju čine stalne rubrike: Uvodna reč; Ženska književnost i kultura; Bibliografije; Intervju; Prikazi; Događaji. Ovih šest rubrika prisutno je u svih šest dosadašnjih brojeva, s tim da samo u prvom broju, pored navedenih, postoji i dodatna rubrika Teorija u žiži $/$ u žiži teorije u kojoj je objavljen jedan naučni rad. Uvodna reč prvog broja predstavlja svojevrsni manifest časopisa u kome je dat pregled njegovih najvažnijih karakteristika i ciljeva, sa naročitim osvrtom na potencijale digitalne humanistike evidentne prije svega $u$ dostupnosti časopisa i umreženosti podataka. Uvodne riječi svih narednih brojeva okrenute su ka specifičnostima svakog pojedinačnog broja i sadrže kratki pregled tematskih fokusa i najvažnije aspekte radova koji će u tom broju biti predstavljeni.

Središnji dio časopisa jeste rubrika Ženska književnost $i$ kultura u kojoj se najvećim dijelom objavljuju originalni naučni radovi, a koja ujedno ima i najveći broj priloga po broju. U prvom broju u ovoj rubrici objavljeno je 9 originalnih naučnih radova, u drugom 10 naučnih radova i jedan pregledni članak, u trećem 7 naučnih radova, 3 pregledna članka, jedan stručni rad, jedna forma kratkog ili prethodnog saopštenja i jedan prozni tekst. Četvrti broj sadrži 10 original-

3 Knjiženstvo, početna strana: http://www.knjizenstvo.rs/index.php 4 Knjiženstvo, početna strana: http://www.knjizenstvo.rs/index.php 5 Knjiženstvo, početna strana: http://www.knjizenstvo.rs/index.php 
nih naučnih radova, jedan pregledni rad, jedno kratko ili prethodno saopštenje, jedan dramski tekst i jedan nekategorisani rad. U petom broju objavljeno je 19 naučnih radova, 3 pregledna rada i 2 stručna rada, dok je u posljednjem do sada objavljenom broju predstavljeno 12 originalnih naučnih radova i jedno kratko saopštenje. U časopisu je, na osnovu navedenih podataka, u rubrici Ženska književnost $i$ kultura do sada objavljeno 67 originalnih naučnih radova, a još jedan naučni rad objavljen je u rubrici Teorija $u$ žiži/u žiži teorije.

Časopis nema precizno definisane temate, ali se u svakom broju izdvajaju najčešce dva tematska fokusa prema kojima je orijentisano nekoliko tekstova, premda ne svi. U gotovo svakom broju pojavljuje se jedan, a negdje i više tekstova posvećenih stvaralaštvu Jelene Dimitrijević. U prvom broju preovladavaju tekstovi posvećeni ženskom književnom stvaralaštvu, a tu su i dva teksta posvećena ženskoj periodici. Za ove dvije oblasti možemo reći da su tematske odrednice časopisa u njegovoj cjelosti jer su razmatranja njihovih različitih aspekata u manjem ili većem broju prisutna u gotovo svim brojevima časopisa. U prvom broju jedan tekst izlazi iz datih tematskih okvira, a tiče se istorijskog položaja žena u Kraljevini Jugoslaviji koji se posmatra kroz prizmu borbe ženskih udruženja za jednakost prava žena i muškaraca. U drugom broju ponavljaju se tematski fokusi ženskog književnog stvaralaštva i ženske periodike, a pored ovih tu je i rad o seksualnoj pedagogiji u Srbiji s kraja 19. i početka 20. vijeka, kao i rad u kome se osvetljuje koncept nomadizma kroz lik i djelo umjetnice Milene Pavlović Barili. U trećem broju tekstovi iz periodike se zajedno sa nekim tekstovima o književnom stvaralaštvu sjedinjuju u zajedničkoj temi o ratu i revoluciji, dok ostali tekstovi broja zadiru u druge, tematski raznolike oblasti. U četvrtom i petom broju tematski fokus su ponovo rat, revolucija, uloga žene u ratu, kao i ženska periodika. Šesti broj časopisa donosi interpretacije različitih aspekata ženskog književnog stvaralaštva, zatim tekst o uticaju britanskih ženskih krugova na Dositeja Obradovića i prosvetiteljstvo, tekst o ulozi ženskih organizacija u ratu, tekst o ženskom identitetu u postjugoslovenskim filmovima četiri filmske režiserke, kao i jedan tekst iz periodike u kojem se razmatraju uređivačke politike časopisa The Freewoman - $A$ Weekly Feminist Review. U petom i šestom broju nalazi se značajan broj tekstova nastalih na osnovu izlaganja na međunarodnoj konferenciji Šta je knjiženstvo?

Rubrika Bibliografije broji ukupno 7 tekstova koji sadrže bibliografske jedinice o srpskim književnicama i časopisima iz perioda od srednjeg vijeka do 1915. godine. U prvom broju data je bibliogra- 
fija sa člancima, studijama i knjigama posvećenim srpskoj vladarki i književnici Jeleni Balšić, zatim selektivna bibliografija posvećena Mini Karadžić Vukomanović i popis članaka objavljenih u ilustrovanoj publikaciji Srpkinja: njezin život i rad, njezin kulturni razvitak i njezina narodna umjetnost do danas koju su priredile istaknute srpske književnice tog doba. Drugi broj donosi spisak članaka, studija i knjiga posvećenih prvoj poznatoj književnici srpskog srednjeg vijeka - monahinji Jefimiji, a zatim i bibliografiju časopisa Ženski svet: list dobrotvornih zadruga Srpkinja, u periodu od 1886. do 1890, koja sadrži 659 bibliografskih jedinica. U trećem broju Knjiženstva predstavljen je drugi dio bibliografije časopisa Ženski svet: list dobrotvornih zadruga Srpkinja sa 631 jedinicom iz perioda od 1891. do 1894. godine. U četvrtom broju predstavljeno je narednih 698 bibliografskih jedinica koje obuhvataju naredne četiri godine izdavaštva časopisa, od 1895. do 1898. godine. Svi navedeni bibliografski podaci predstavljaju značajnu bazu za buduća istraživanja autorki čija je vrijednost zbog nepravednog isključivanja iz istorijskih i kulturnih tokova samo djelimično rekonstruisana. U posljednja dva broja nema tekstova u rubrici Bibliografije, ali njen ustaljeni položaj u korpusu časopisa nagovještava da se radi o stalnoj rubrici.

Rubrika posvećena intervjuima broji ukupno 7 razgovora (svaki broj donosi po jedan intervju, osim broja $4 \mathrm{u}$ kojem su predstavljena dva) sa sagovornicama čija su istraživanja i promišljanja doprinijela razvoju feminističke teorije i ženskog stvaralaštva, a one su, i to hronološkim redoslijedom od prvog ka posljednjem broju: Suzan van Dijk (Susan van Dijk), Nataša Marković, Mari Luiz Kolahan (Mary Louise Callahan), Ana Jovanović, An Birgit Roning (Ann Birgit Ronning), Henrijet Pač (Henriette Patch) i Slobodanka Peković.

Rubriku Prikazi sačinjavaju tekstovi (ukupno 38 tekstova) koji su $\mathrm{u}$ jednom širem smislu fokusirani na žensko stvaralaštvo i žensku perspektivu, književnu istoriografiju i položaj koji u njoj spisateljice zauzimaju; teoriju roda, feminističku teoriju i kritiku, kao i ženske emancipatorske diskurse. Objavljivanjem prikaza različitih pitanja iz pomenutih oblasti časopis doprinosi širenju feminističkog znanja i služi kao forum za šira teorijska pitanja.

U rubrici Događaji predstavljeno je ukupno 11 različitih manifestacija značajnih za žensko stvaralaštvo i afirmaciju ženskog glasa. Godine 2011. predstavljen je međunarodni skup Međunarodne ženske mreže (International Female Networks) održan na Filološkom fakultetu u Beogradu. Godinu 2012. obilježila je radionica Ženska književnost i veze Istoka i Zapada u Evropi: Vizualizacija poveza- 
nosti održana u Bukureštu na Univerzitetu Spiru Haret, kao i izložba Re/vizija: časopisi kao agensi književnosti i kulture, održana u holu Narodne biblioteke Srbije, u organizaciji Instituta za književnost i umetnost u Beogradu, kojom je obilježeno pola vijeka rada ove ustanove i 42 godine postojanja istraživačkog projekta usmjerenog na proučavanje književne periodike. Godina 2013. upamćena je kao godina u kojoj je Alis Manro (Alice Munro) primila Nobelovu nagradu za književnost i cjelokupno životno djelo, postavši tako trinaesta žena kojoj je dodijeljeno ovo priznanje. Iste godine je u beogradskom Pedagoškom muzeju, na sto pedesetu obljetnicu od osnivanja Više ženske škole u Beogradu, predstavljena knjiga Ljiljane Stankov o Katarini Milovuk, prvoj upraviteljki Više ženske škole Katarina Milovuk (1844-1913). U četvrtom broju izdvaja se okrugli sto na temu Književno stvaralaštuo Milice Janković održan 2014. godine $e^{6} \mathrm{u}$ Narodnoj biblioteci "Vuk Karadžici" u Velikom Gradištu u pomen 75 godina od smrti srpske književnice Milice Janković. Godina 2015. značajna je zbog međunarodne naučne konferencije Šta je Knjiženstvo? održane na Filološkom fakultetu u Beogradu. Na konferenciji su artikulisana pitanja koja su u osnovi projekta Knjiženstvo: digitalna humanistika, žensko iskustvo i feministički pristup književnosti i istoriji. Konferencija je upotpunjena i pratećim manifestacijama kao što su: radionica o ženskoj periodici i bazama podataka, promocija knjige o ženskom dramskom stvaralaštvu Žene, drama i izvedba: između post-socijalizma i post-feminizma, izložba Šta je Knjiženstvo?, a objavljen je i zbornik radova Knjiženstvo, teorija i istorija ženske književnosti na srpskom jeziku do 1915. godine. Još jedna istraživačka aktivnost u okviru projekta Knjiženstvo održana je 2016. godine na Filološkom fakultetu u Beogradu. Riječ je o okruglom stolu o radu i delu Jelene Dimitrijević. Drugi izdvojeni događaj jeste panel diskusija pod nazivom Da li je moguća rekonstrukcija "horizonta nade"? održana povodom knjige Marine Hjuson (Marina Hughson) Sutraje bilo juče: prilog društvenoj istoriji žena u Jugoslaviji, u drugoj polovini 20. veka u organizaciji Sociološkog kluba Filozofskog fakulteta u Beogradu. Događaj kojim je zaključena 2016. godina još je jedna u nizu aktivnosti istraživačkog projekta Knjiženstvo: skup pod nazivom $J e-$ lica Belović Bernadžikovska - etnografkinja, pedagoškinja, književnica..., koji je pored učesnica iz regiona okupio i učesnice iz SAD-a.

6 Iste godine obilježeno je i šezdeset godina postojanja Katedre za opštu književnost i teoriju književnosti na Filološkom fakultetu u Beogradu, a tim povodom na ovom fakultetu održan je međunarodni naučni skup pod nazivom "Komparativna književnost: teorija, tumačenja, perspektive”. 


\section{ŽENSKA I FEMINISTIČKA PERIODIKA U ČASOPISU "KNJIŽENSTVO"}

Kao što je već napomenuto, u časopisu Knjiženstvo nisu definisane teme brojeva, ali se u svakom broju mogu izdvojiti jedan ili dva tematska fokusa na koje se oslanja određeni broj tekstova. Tema svakog broja je žensko književno stvaralaštvo, a pod ovom opštom odrednicom se podrazumijevaju radovi koji zalaze u različita pitanja specifičnosti ženskog pisanja i ženskog autorstva. Drugi značajan tematski fokus jeste ženska i feministička periodika, a tekstovi iz ove oblasti prisutni su u svih šest do sada objavljenih brojeva. Autorke koje su do sada u Knjiženstuu objavljivale na ovu temu su: Ana Kolarić (5 radova), Jelena Milinković ( 2 rada), Stanislava Barać (2 rada), Jelena Josipović (2 rada), Slobodanka Petković, Neda Todorović, Katerina Dalakura (Katerina Dalakoura), Cvetana Krstić, Miloš Utvić, Jelena Jaćimović. Evidentno je da su neke autorke tokom šest godina postojanja časopisa objavile dva i više rada iz ove oblasti, što znači da postoji grupa istraživačica koje feminističku teoriju i kategoriju roda posmatraju polazeći od periodike. Ova oblast je kod nas malo istražena, što ostavlja prostor za dalju analizu pomenutim afirmisanim, ali i nekim budućim autorkama. Proučavanje ženske periodike je značajno jer nam pokazuje kako se naše viđenje određenog perioda mijenja kada umjesto muškog u središte stavimo žensko viđenje, a u osnovi ovakve inverzije jeste uzimanje učešća u istoriji književnosti i kulture u svrhu rekonstrukcije prošlosti i legitimizacije ženskog glasa.

Iz oblasti periodike, najviše radova je napisano o časopisu Žena (5 radova) koji je izlazio u drugoj deceniji dvadesetog vijeka, a pored njega tu su i časopisi Ženski svet s kraja 19. i početka 20. vijeka (1 rad), kao i časopis Žena i svet (1 rad) aktuelan u trećoj i četvrtoj deceniji 20. vijeka. Predstava o ženi i njenoj društvenoj poziciji analizirana je na odabranom korpusu preuzetom iz modnih magazina (1 rad), savremene štampe od 1960. do 1986. godine (1 rad) i srpske dnevne štampe u periodu od 2009. do 2015. godine (1 rad). Pored radova u kojima se analiziraju različiti segmenti domaćih časopisa, tu su i radovi o stranim časopisima, konkretno o britanskom feminističkom časopisu The Freewoman (2 rada), španskom časopisu La voz de la mujer (1 rad), a pitanje obrazovanja u otomanskoj Grčkoj posmatra se kroz nekoliko grčkih časopisa koji su izlazili u periodu od 1845. do 1907. godine (1 rad). Tekst Stanislave Barać o Devojačkom romanu možemo svrstati u radove o periodici jer je sam roman definisan kao granični žanr između književnosti i periodike i smatra se kontekstualno neodvojivim od časopisne cjeline. 


\section{ČASOPIS "ŽENA" U "KNJIŽENSTVU"}

O časopisu Žena u Knjiženstuu se pisalo u više navrata, a do sada je u ovoj kategoriji predstavljeno pet radova - radovi Ane Kolarić "Žena, domaćica, majka. Od te tri riječi zavisi ceo svet: analiza časopisa Žena (1911- 1921)" (prvi broj/2011), "Svi smo mi ljudi jednaki, a što je neko malo crnji, a neko malo belji ne menja stvar'. Seksualna pedagogija u Srbiji na kraju 19. i početku 20. veka" (drugi broj/2012) i "Što nisam muško?!: predstave o vezi između žene i nacije u časopisu Žena u ratnim i poratnim godinama (1911- 1921)" (treći broj/2013), kao i radovi Jelene Milinković "Književnosti između emancipacije i nacionalnog - književni prilozi u časopisu Žena" (drugi broj/2012) i "Rat kao tema u srpskoj periodici i književnosti početkom XX veka - Žena, Srpski književni glasnik i ratna proza Milice Janković i Isidore Sekulić" (treći broj/2013). Prostor posvećen analizi ovog časopisa potvrđuje da su njegovi sadržaji svjedočanstva od istorijskog značaja koja nam omogućavaju da steknemo uvid u istorijat ženske emancipacije u Srbiji.

U prvom dijelu rada "Žena, domaćica, majka. Od te tri riječi zavisi ceo svet: analiza časopisa Žena (1911- 1921)”, Ana Kolarić predstavlja teorijsko-kritički okvir za analizu ženskih časopisa na srpskom jeziku s početka 20. vijeka, dok u drugom dijelu konkretne segmente iz časopisa interpretira u skladu sa postavljenim okvirom. Autorka najpre skreće pažnju na koncept politike mesta (politics of location) koji feministička teoretičarka Edrijen Rič (Adrienne Rich) koristi da ukaže na to da feministički pokret ima različite ciljeve i strategija u zavisnosti od specifičnosti konteksta u kom se javlja. U daljem toku rada, Ana Kolarić ukazuje na razlike između američkog i evropskog, ili preciznije francuskog feminizma, a potom prelazi na ocrtavanje pojmova relacione i individualističke feminističke tradicije, pojašnjavajući da je osnova prve nehijerarhijski ustrojena zajednica između muškarca i žene, a druge individua nezavisna od polnih i rodnih odrednica. Autorka teorijsku okosnicu zaokružuje konceptima izraelske teoretičarke Nire Juval-Dejvis (Nira Yuval-Davis) predstavljenim u njenoj knjizi Rod i nacija, u kojoj se ispituju odnosi između nacionalističkih ideologija i rodnih odnosa. Nakon ovoga, u radu je dat političko-istorijski kontekst vezan za period izlaženja časopisa, kao i osnove uređivačke politike koje su bile usko vezane za lično političko opredjeljenje njegove urednice Milice Tomić.

U drugom dijelu rada, autorka u skladu sa predstavljenom teorijsko-konceptualnom bazom analizira odabrane priloge iz časopisa Žena. Odabrani tekst naslova "Krajnja cel žene" smatra se jednim od reprezentativnijih tekstova na temu emancipacije, a u njemu je pred- 
stavljen razgovor Jaše Tomića i četiri žene. U tom razgovoru, Tomić za emblematičnu sliku kalendara za 1912. godinu predlaže prizor žene koja iz provalije izlazi zahvaljujući muškarcu koji joj pruža ruku. To izaziva negodovanje njegovih sagovornica. U skladu sa referentnim teorijskim okvirom, autorka zaključuje da bi stav Jaše Tomića mogao da se vidi kao odjek stanovišta relacione feminističke tradicije, dok je intervencija njegovih sagovornica glas individualističke feminističke tradicije. Analiza ovog segmenta pokazuje da je i u tadašnjim savremenim emancipatorskim diskursima djelovanje žene bilo ograničeno na suženi krug domaćinstva i porodice, ali isto tako da je časopis Žena bio intelektualni prostor u kome je moglo da se predstavi i alternativno shvatanje o ženi i njenoj ulozi u društvu. Još jedan pokazatelj bliskosti naših feminističkih orijentacija iz prvih decenija 20. vijeka sa relacionom feminističkom tradicijom jeste osuda nasilne borbe za pravo glasa kojoj su u jednom trenutku pribjegle žene u Engleskoj, iz razloga što je takav čin u suprotnosti sa ženskom prirodom i kultom ženstvenosti. Teorija Nire Juval-Dejvis (Nira Yuval-Davis) o preplitanju nacionalističkih projekata i roda očitava se u tekstu urednice časopisa Milice Tomić o neophodnosti obrazovanja žena. Ana Kolarić analizom ovog teksta osvetljava ključnu odliku tadašnjeg pokreta emancipacije: borba za ženska prava neodvojiva je od nacionalnih interesa, a emancipacija je moguća samo pod uslovom da se odvija pod okriljem nacionalno-oslobodilačkog pokreta i u skladu sa patrijarhalno-tradicionalnim normama, što potvrđuje i docnija analiza Jelene Milinković. Žena ne zahtjeva obrazovanje jer joj, kako Kolarić pojašnjava, po prirodi pripada, već da bi naučila kako da bude bolja majka i Srpkinja, pa je u skladu sa ovim shvatanjem ideal emancipovane žene tog doba predstavljen u gradacionom nizu od tri riječi: žena, domaćica, majka, preko kojeg se manifestuju tri glavne uloge žene: biološko-seksualna, vaspitačka i reproduktivna. Ana Kolarić dalje precizira pravac kretanja pomenutih uloga u datom istorijskopolitičkom kontekstu, zaključujući da se od tadašnje emancipovane žene očekivalo da rađa djecu, prenosi nacionalnu tradiciju i kulturu i brani naciju od navodnih štetnih uticaja Zapada, kao i da su se zahtjevi žena ticali grupnih prava usmjerenih isključivo ka nacionalnim interesima. Uzimajući u obzir sve te činjenice, autorka ukazuje na značaj teze Karen Ofen (Karen Ofen) da je istorijsko razumjevanje feminizma ključno za njegov sadašnji i budući angažman.

Jelena Milinković u radu "Književnosti između emancipacije i nacionalnog - književni prilozi u časopisu Žena” kroz analizu književnih priloga istražuje ulogu književnosti u emancipatorskim procesima 
u Srbiji s početka 20. vijeka. Autorka na samom početku uobličava kontekst u kojem se časopis razvija, ukazujući na to kako su politička ideologija osnivačice časopisa Milice Tomić i njenog muža Jaše Tomića u znatnoj mjeri odredili profesionalni i idejni tok samog časopisa. Njihova ideologija simbolizovala je društveno dominantnu ideologiju epohe utemeljenu na nacionalno-patrijarhalnom diskursu koji je oblikovao sve društvene procese, uključujući i emancipaciju žena. Autorka u skladu sa društvenim i kulturnim kontekstom tadašnjice određuje karakter književnih priloga u časopisu ocjenjujući ih kao tendenciozne, pri čemu se, kako Jelena Milinković u nastavku precizira, njihova tendencija ispoljava u dva pravca: u pravcu emancipacije žena i u pravcu podizanja nacionalne svijesti. Glavni ciljevi časopisa bili su usmjereni ka obrazovanju nacije i ka oblikovanju i usavršavanju njenih moralnih i intelektualnih vrijednosti, $\mathrm{u}$ čemu se ogleda njegova prosvjetiteljska utemeljenost. U cilju ispunjenja programskih ciljeva, književni tekstovi su pisani prijemčivim jezikom pa su tako estetska i formalna dimenzija ostajale podređene poruci i osnovnoj ideji časopisa. U kontekstu ženskog pitanja, kroz opšti diskurs časopisa zastupana je ideja o neophodnosti emancipacije, ali se ta emancipacija odvijala isključivo u okviru granica patrijarhata i bila snažno uslovljena rodnim obrascima i ulogama, što je značilo da se obrazovanje žene nije promovisalo zarad žene same i zarad njenog ličnog intelektualnog razvoja, već je bilo u službi nacije i patrijarhata kome je obrazovana žena bila potrebna kao njegovateljica i vaspitačica budućih pokolenja. Autorka u nastavku zaključuje da su ove i slične ideje koje su predstavljene u književnim prilozima Žene paradigmatske za feminističke orijentacije u srpskoj kulturi početkom 20. vijeka.

U eseju "Što nisam muško?!: predstave o vezi između žene i nacije u časopisu Žena u ratnim i poratnim godinama (1911- 1921)", objavljenom u trećem broju Knjiženstva, Ana Kolarić na osnovu književnih priloga istražuje shvatanja o ulozi žene u vrijeme balkanskih ratova i po završetku Prvog svjetskog rata. U prvom dijelu autorka predstavlja osnovne teorijsko-kritičke koncepte preuzete iz tekstova Tri gvineje Virdžinije Vulf (Virginia Woolf) i Rod i nacija Nire Juval-Dejvis. Virdžinija Vulf zastupa stanovište da su političke i državne institucije formirane na osnovu zahtjeva i potreba muškaraca, te da u takvom kontekstu specifična perspektiva koju žene posjeduju, i koja im omogućava da stvari sagledaju iz drugačijeg ugla, ne može da donese pozitivne ishode. Progres žena Virdžinija Vulf vidi u otporu patrijarhalnom sistemu i osnivanju alternativnog ženskog udruženja "Udruženje marginalki", čime ona ustvari zastupa kontradiktoran 
stav jer, kako Kolarić primjećuje, upućuje zahtjeve državi o jednakom pristupu obrazovanju, zaposlenju, kulturnoj i intelektualnoj svojini, ali to čini sa pozicije koja je izvan, ili pak na marginama države. Za razliku od stanovišta Virdžinije Vulf, Nira Juval-Dejvis smatra da je žena uvijek unutar države, premda je isključena iz političke zajednice i u njoj ima funkciju objekta. Ana Kolarić prikazuje osnovne teze o odnosu između roda i nacije pojašnjavajući tri dimenzije nacionalnih ideologija koje uvodi Juval-Dejvis: genealošku, kulturnu i građansku. Još jedna značajna teza Nire Juval-Dejvis, koju će autorka primijeniti u svom istraživanju, tiče se prevazilaženja politike identiteta koja je ostvariva usvajanjem transverzalne politike zasnovane na ideji ukorjenjivanja i premještanja. Ukorjenjivanje podrazumijeva činjenicu da svaka žena sa sobom nosi vlastiti identitet i pripadanje određenoj etničkoj i kuturnoj zajednici, dok premještanje znači da ona može istovremeno da ulazi u dijalog i razmjenu sa ženama različitog članstva i identiteta.

U drugom dijelu eseja vrši se analiza ženskih uloga u balkanskim ratovima na osnovu korpusa reprezentativnih književnih priloga čija je funkcija primarno prosvetiteljska i propagandna, a ovim funkcijama su, kako Kolarić naglašava, podređene i njihova estetska i književna vrijednost. Autorka identifikuje tri osnovne ženske uloge u ratu: idealizovana žena (majka, supruga, ćerka), bolničarka i delija djevojka, kao i dvije ženske pozicije koje iz njih proizilaze: žena u kući i žena na frontu. Ona potom ukazuje da su ove uloge zasnovane na opštim mjestima iz kosovskog mita koji se nameće kao normativni okvir dejstvovanja i ponašanja u periodu rata, pa su tako ove tri identifikovane uloge varijacija uloga personifikovanih kroz likove majke Jugovića, kneginje Milice i Kosovke djevojke.

Analizom konkretnih fragmenata književnih tekstova autorka pokazuje kako je slika idealizovane žene zasnovana na diskursu poslušnosti i lojalnosti naciji i opštim nacionalim ciljevima, ali da postoje segmenti u kojima se može prepoznati kritički ton prema ratu i njegovim posljedicama. Propagiranje odanosti zajedničkom parijarhalnom cilju Ana Kolarić ilustruje pomoću nekoliko književnih tekstova, od kojih izdvajam pjesmu "Srpska majka" u kojoj je prikazana majka koja se povratku sina iz rata u potpunosti raduje tek kada vidi njegovu ranu koja predstavlja simbol ratne časti. U pjesmi "Petkovića majci" naglasak je na biološkoj funkciji žene, što je jedna od tri dimenzije nacionalnih i konzervativnih projekata koje opisuje Nira Juval-Dejvis. Petkovića majka je okarakterisana kao nasljednica majke Jugovića jer svom narodu daruje deset sinova za rat, čime se, kako je analizom po- 
kazano, prenosi propagandna poruka po kojoj je dužnost svake srpske majke da poslušno i mirno sinove daje u rat. Kritički ton prema ratu osjetan je u priči "Mati" u kojoj se pomoću slike sina ratnog invalida problematizuje žrtva koju pojedinac polaže za kolektiv, kao i načelno pitanje o smislu rata. Kroz predstavu žene kao bolničarke reflektuje se njena patrijarhalno zasnovana uloga njegovateljice i zaštitnice, ali se žena kroz ovu ulogu, kako Kolarić zapaža, istovremeno približava muškoj sferi, zato što radi i zato što se brine o bespomoćnim muškarcima, što žene na ljestvici moći rangira na višu poziciju u odnosu na same muškarce. Naposlijetku, ženska ratna uloga koja najdrastičnije izlazi iz patrijarhalnih okvira jeste uloga djevojke delije koja se prerušava i preuzima mušku rodnu ulogu, a ovakvu zamjenu autorka ilustruje na primjeru priče "Četnik Sofronije”, gdje je Sofronije ustvari krojačica Sofija koja je odlučna da nastavi očevu borbu za nacionalne interese.

Ana Kolarić na osnovu sprovedene analize zaključuje da su žene u ratnom periodu ispunile sve uloge koje im je društvo dodijelilo i time dokazale svoju odanost naciji, pokazujući da u mnogim aspektima mogu da budu jednake muškarcima. Zahvaljujući ovakvom ratnom angažmanu, žene su u posleratnim godinama stekle kredibilitet da traže pravo glasa i građansku ravnopravnost.

U radu "Svi smo mi ljudi jednaki, a što je neko malo crnji, a neko malo belji, ne menja stvar'. Seksualna pedagogija u Srbiji na kraju 19. i početku 20. veka" Ana Kolarić na primjerima iz priručnika seksualne pedagogije Petra Ilića i tekstova iz časopisa Žena analizira kulturalne i pedagoške diskurse seksualnosti u Srbiji s kraja 19. i početka 20. vijeka. Časopis Žena je u Srbiji predstavljao jedan vid neformalnog obrazovanja te je u skladu sa ovom funkcijom u sebi sažimao i brojne tekstove iz oblasti seksualne pedagogije, a mnogi od njih preuzimani su iz sfera formalnog obrazovanja, pri čemu treba izdvojiti odlomke i tekstove iz Ilićeve seksualne pedagogije, kao i tekstove evropskih autora koji su u to vrijeme smatrani stručnjacima u pogledu ove tematike. Teorijsko uporište na koje se autorka oslanja su uvidi Džordža Mosa (George L. Mosse), istoričara moderne evropske kulture i Roberta Janga (Robert J. C. Young), postkolonijalnog teoretičara, kritičara i profesora književnosti, a neizostavna su i razmatranja teoretičarke roda Nire Juval-Dejvis.

Kroz analizu priloga iz časopisa Žena autorka pokazuje da je ideja o zdravoj i snažnoj srpskoj naciji ključna za seksualnu pedagogiju tog perioda. Na ovaj način koncipirano seksualno obrazovanje suštinski je podrazumijevalo nametanje "ispravnog” seksualnog ponašanja 
koje je bilo u funkciji formiranja moralnih načela koja su se smatrala krucijalnim za konstruisanje identiteta mladih. Seksualno obrazovanje je kroz postojeće diskurse ideju o pojedincu kao autonomnom biću sa pravom na samostalno raspolaganje vlastitim tijelom potiskivalo zarad osnaženja ideje o neophodnosti biološke reprodukcije kao temelja zdravog srpskog društva. U kontekstu nacionalističkih reproduktivnih politika autorka ukazuje na prisustvo tri dominantna diskursa u srpskoj seksualnoj pedagogiji: eugenički diskurs, maltuzijanski diskurs i diskurs "ljudi kao moć", koje potkrepljuje konkretnim primjerima iz časopisa Žena. Autorka na kraju zaključuje da su svi pomenuti obrasci poimanja seksualnosti i tjelesnosti u našoj tradiciji doslovno preuzimani iz evropske literature, kao i da su Srbi svoj nacionalni identitet gradili oscilirajući između dva fundamentalna uticaja: "divljaka" kao negativne slike i "kulturnih evropskih naroda" kao pozitivne slike kojoj treba težiti.

U radu "Rat kao tema u srpskoj periodici i književnosti početkom XX vijeka - Žena, Srpski knjižeuni glasnik i ratna proza Milice Janković i Isidore Sekulić” Jelena Milinković pokazuje kako je promjena geopolitičke situacije u periodu Prvog balkanskog rata uticala na promjenu ideološke matrice uočljive u periodici i u književnim djelima. Ideološko-političko opredjeljenje u ovom periodu zasnivalo se na buđenju nacionalne svijesti i jačanju patriotskog naboja, što je rezultiralo promjenom u uređivačkoj politici časopisa Žena u kojem je evidentan zaokret od predratnih emancipatorsko-feminističkih orijentacija ka nacionalno-oslobodilačkim politikama. U skladu sa promjenom orijentacije, u časopisu su u ovom ratnom periodu dominirali književni tekstovi sa rodoljubivim motivima i izraženim nacionalnim osjećanjem, a nezaobilazno je bilo i evociranje kosovskog kulta i romantizovane prošlosti junaka i junakinja srpske istorije i epike.

Časopis je, kako Jelena Milinković naglašava, i prije rata bio u službi širenja ideologije zasnovane na ličnom političkom ubjeđenju urednika, a ova praksa odredila je i njegov tok u ratnim godinama, tako da su tekstovi objavljeni u ovom periodu produkt opšteg pragmatičnog pristupa uredništva koje javnosti prezentuje tendenciozne književne tekstove koji sa ostalim prilozima u časopisu čine jedinstvenu tematsko-ideološku cjelinu. Urednica časopisa Milica Tomić, kao i njen muž Jaša Tomić, imali su aktivnu ulogu u konstruisanju nacionalno-patrijarhalnih diskursa, a oboje su izvještavali i pisali sa ključnih ratnih pozicija - Jaša Tomić sa ratišta, a Milica Tomić iz bolnica.

Jelena Milinković kao posebno upečatljiv izdvaja fikcionalni izvještaj "Pismo sa bojišta" u kojem izvještač-narator daje svoje viđenje 
žene u ratu opisujući njene doprinose prvo preko banalnih kućnih poslova, da bi zatim ukazao na njeno stoičko podnošenje ratnih nedaća i na njen opšti doprinos srpskoj oslobodilačkoj istoriji. Autor sa posebnim poštovanjem piše o bolničarkama koje su u ratnim godinama uživale naročito poštovanje jer je njihova ratna angažovanost, kako Jelena Milinković primjećuje, a prethodno i Ana Kolarić, pokazatelj prelaska žene iz privatne u javnu sferu i doprinos promjeni percepcije ženskih uloga. U kontekstu promjene ženske uloge u ratnom periodu značajna je priča "Četnik Sofronije" koju analizira i Ana Kolarić, s tim da je u njenoj interpretaciji naglašeno žensko preuzimanje muške rodne uloge, dok Milinković akcenat stavlja na sticanje nove ženske uloge - žene ratnice.

Autorka kao naročito reprezentativnu izdvaja reportažu Milice Tomić "Iz bolnice u bolnicu - Ranjenici” koja je značajna kao svjedočanstvo o bolničkom životu u kome je posebno naglašena uloga bolničarke, što je u skladu sa emancipatorskim idejama časopisa, ali i po negativno-propagandnoj tendenciji usmjerenoj prema Albancima. Milica Tomić Albance u skladu sa tadašnjim reprezentativnim politikama opisuje kao krvoločne i brutalne, više zverskog no ljudskog naličja. Jelena Milinković ovdje ukazuje na dvije stvari: na mjeru u kojoj je u časopisu Žena bila zastupljena propaganda, ali i na njen uspjeh ilustrovan na primjeru Milice Tomić koja vjeruje u nacionalne stereotipe i nastavlja da ih širi u svojim tekstovima.

\section{OPŠTE KARAKTERISTIKE SRPSKIH EMANCIPATORSKIH DISKURSA S POČETKA 20. VIJEKA}

Analize časopisa Žena koje su sprovele Ana Kolarić i Jelena Milinković prepliću se i nadopunjavaju na tematskom i idejnom planu. Obje autorke kroz analizu različitih segmenata časopisa osvetljuju istorijski, kulturni i političko-ideološki kontekst u kojem se odvijala ženska emancipacija na početku 20. vijeka, a svojom djelatnošću istovremeno odgovaraju na teorijske zahtjeve Karen Ofen (Karen Ofen) koja zastupa stanovište da je istorijsko razumjevanje feminizma važno za njegov sadašnji i budući angažman.

U zajedničkom postupku rekonstrukcije prošlosti iz perspektive feminističke teorije, obje autorke iznose suštinski iste zaključke: emancipatorski procesi na prostoru južne Ugarske i Kneževine Srbije s početka 20. vijeka odvijali su se pod okriljem nacionalno-patrijarhalnog poretka u kojem je ženski identitet definisan preko rodnih uloga i u kojem je emancipacija bila moguća samo u okvirima propisanih obra- 
zaca ponašanja usmjerenih ka opštoj dobrobiti nacije. Sistem zasnovan na patrijarhalnim vrijednostima obrazovanje žene ne posmatra kao pitanje njenog prirodnog prava na lični intelektualni razvitak, već ga koristi kao strateško sredstvo daljeg produbljivanja ženske uloge vaspitačice nacije. U skladu sa promjenom političke situacije i ideoloških orijentacija, prije svega u zavisnosti od odnosa rata i mira na ovim prostorima, mijenjala se i predstava o emancipovanoj ženi koja je u svim svojstvima djelovanja - kao žena, majka, domaćica, vaspitačica, bolničarka, ratnica - predstavljala objekat pomoću kojeg se održavala i prenosila određena tradicija. Analize autorki nam predočavaju izrazito nepovoljan kulturno-istorijski kontekst u kojem su se formirale srpske emancipatorske politike, ali nam isto tako sugerišu da je njihovo postojanje i razvijanje u jednom takvom kontekstu samo po sebi značajan progresivni pomak. U tom smislu, jasno je i da uočljiva kontradiktornost između patrijarhalne i emancipatorske orijentacije ličnosti poput Milice Tomić dolazi kao rezultat istorijskog konteksta epohe kojoj je pripadala, a s obzirom na ograničenja i stege patrijarhata, usklađivanje emancipatorski orijentisanog časopisa prema tadašnjim društvenim normama može se smatrati njenim velikim uspjehom.

\section{ZAKLJUČAK}

Časopis Knjiženstvo se naslanja na tradiciju dugu preko dvije decenije koja je pokrenuta i očuvana zahvaljujući naporima Centra za ženske studije pod čijim okriljem od 1995. do 2002. godine izlazi časopis Ženske studije, koji 2002. godine mijenja ime u Genero: časopis za feminističku teoriju, a od 2008. godine naovamo ima naslov Genero: časopis za feminističku teoriju i studije kulture; kao i časopisa za žensku književnost i kulturu ProFemina, koji se takođe izdaje od 1995. godine, ali i časopisa Feminističke sveske (ProFemina i Feminističke sveske više se ne objavljuju). Ovi časopisi, kojima je prethodila istrajna borba ženskog pokreta, otvorili su put afirmaciji ženske književnosti i teorijskih i kritičkih okvira njene interpretacije, profilisali feminističku (kontra)javnost u Srbiji i stvorili uslove za nastanak projekta i časopisa Knjiženstvo kojim se nastavlja afirmacija ženske književnosti i feminističke teorije preko savremenih dostignuća digitalne tehnologije.

Istraživanja koja se objavljuju u časopisu Knjiženstvo obično imaju za cilj reviziju književne istorije i teorije i rekonstrukciju pitanja ženske uloge i pozicije u istorijsko-kulturnom kontekstu prošlih epoha, 
čime se uspostavlja intervencija na polju istorije i kulture. U ovom radu za konkretne primjere ovakve intervencije odabrani su tekstovi Ane Kolarić i Jelene Milinković jer su obe autorke na osnovu analize priloga iz časopisa Žena osvetlile karakteristike emancipatorsko-feminističkih diskursa u Srbiji s početka 20. vijeka.

\section{LITERATURA}

Kolarić, Ana. "Žena, domaćica, majka. Od te tri reči zavisi ceo svet: analiza časopisa Žena (1911-1921)”. Knjiženstvo, br. 1, 2011, dostupno na http://www.knjizenstvo.rs/magazine.php?text=26.

Kolarić, Ana. “'Svi smo mi ljudi jednaki, a što je neko malo crnji, a neko malo belji, ne menja stvar'. Seksualna pedagogija u Srbiji na kraju 19. i početku 20. veka”. Knjiženstvo, br. 2, 2012, dostupno na http://www.knjizenstvo.rs/magazine.php?text=44.

Kolarić, Ana. "Što nisam muško?!: predstave o vezi između žene i nacije u časopisu Žena u ratnim i poratnim godinama (1911- 1921)”. Knjiženstvo, br. 3, 2013, dostupno na http://www.knjizenstvo.rs/ magazine.php?text=88.

Milinković, Jelena. "Književnosti između emancipacije i nacionalnog - književni prilozi u časopisu Žena”. Knjiženstvo, br. 2, 2012, dostupno na http://www.knjizenstvo.rs/magazine.php?text=43.

Milinković, Jelena. "Rat kao tema u srpskoj periodici i književnosti početkom XX veka - Žena, Srpski književni glasnik i ratna proza Milice Janković i Isidore Sekulić”. Knjiženstvo, br. 3, 2013, dostupno na http://www.knjizenstvo.rs/magazine.php?text=89

Knjiženstvo, časopis za studije književnosti, roda i kulture. http:// www.knjizenstvo.rs/magazine.php?text=89> (Pristupljeno 30. jul 2017).

\section{THE WOMEN'S AND FEMINIST PERIODICALS}

\section{STUDIES IN THE JOURNAL "KNJIŽENSTVO"}

Knjiženstvo: Journal for Studies in Literature, Gender and Culture represents a part of the digital humanities project Knjiženstuo, Theory and History of Women's Writing in Serbian until 1915, which was initiated in 2011. The start of the journal is closely connected to the context outlined by journals issued by the Women's Studies Centre since the 1990s - Ženske studije 
[Women's Studies] (1995-2002) and Genero (2002-). In the first part of the paper, the focus is on the analysis of the general qualities of the journal: its main characteristics, goals and structure; while, in the second part, the focus will be on papers on women's and feminist periodicals. The analysis will be limited to the texts of Ana Kolarić and Jelena Milinković dedicated to the magazine Žena [The Woman], since most of the papers in that area (a total of five papers) were written about that magazine. The representation of this magazine confirms that this is a significant source from which the position of women in the historical and cultural context of the epoch can be reconstructed. The analysis of the aforementioned papers includes examining the most important aspects that the authors present, and attempting to summarise their conclusions for the purpose of forming a general image about the emancipatory discourses in Serbia at the turn of the $20^{\text {th }}$ century.

Keywords: Knjiženstuo, Žena, Milica Tomić, periodical studies, emancipatory-feminist discourses in Serbia at the turn of the $20^{\text {th }}$ century 